\title{
Expression of Concern: BRG1 regulation by miR-155 in human leukemia and lymphoma cell lines
}

\author{
M. Cuadros ${ }^{1,2} \cdot$ V. Sánchez-Martín ${ }^{1,2}$ (1) A. Herrera-Merchan ${ }^{2,3} \cdot$ C. Baliñas $^{2} \cdot$ J. Martín-Padrón $^{1,2} \cdot$ L. Boyero ${ }^{1,2}$. \\ P. Peinado ${ }^{2,3}$. P. P. Medina ${ }^{2,3}$
}

๑) Federación de Sociedades Españolas de Oncología (FESEO) 2019

\section{Expression of Concern:}

Clin Transl Oncol (2017) 19:1010-1017

https://doi.org/10.1007/s12094-017-1633-2

The Editor-in-Chief is issuing this editorial Expression of Concern to alert readers that there is a dispute amongst the authors over whether Antonio Herrera-Merchan qualifies for authorship of the original article.

The institution where this research took place has been unable to contact all authors to resolve this dispute.

Antonio Herrera-Merchan has agreed to the publication of this Expression of Concern.
Marta Cuadros, Victoria Sánchez-Martín, Carlos Baliñas, Laura Boyero, Paola Peinado, Pedro Medina did not agree to the publication of this Expression of Concern.

Joel Martin-Pedron did not respond to the correspondence from the journal regarding this Expression of Concern.

Publisher's Note Springer Nature remains neutral with regard to jurisdictional claims in published maps and institutional affiliations.

The original article can be found online at https://doi.org/10.1007/ s12094-017-1633-2.

1 Department of Biochemistry and Molecular Biology III and Immunology, University of Granada, Granada, Spain

2 GENYO, Centre for Genomics and Oncological Research, Granada, Spain

3 Department of Biochemistry and Molecular Biology I, University of Granada, Granada, Spain 